\title{
Comparative analyses of genetic/epigenetic diversities and structures in a wild barley species (Hordeum brevisubulatum) using MSAP, SSAP and AFLP
}

\author{
X.H. Shan ${ }^{1 *}$, Y.D. Li ${ }^{2 *}$, X.M. Liu ${ }^{3}$, Y. Wu ${ }^{1}$, M.Z. Zhang ${ }^{1}$, W.L. Guo ${ }^{2}$, \\ B. Liu ${ }^{3}$ and Y.P. Yuan ${ }^{1}$ \\ ${ }^{1}$ College of Plant Science, Jilin University, Changchun, P.R. China \\ ${ }^{2}$ Biotechnology Research Centre, Jilin Academy of Agricultural Sciences, \\ Changchun, P.R. China \\ ${ }^{3}$ Key Laboratory of Molecular Epigenetics of MOE, \\ Institute of Genetics and Cytology, Northeast Normal University, \\ Changchun, P.R. China \\ *These authors contributed equally to this study. \\ Corresponding authors: B. Liu / Y.P. Yuan \\ E-mail: baoliu6677@yahoo.com.cn / yapingyuan@yahoo.com.cn
}

Genet. Mol. Res. 11 (3): 2749-2759 (2012)

Received November 3, 2011

Accepted May 20, 2012

Published August 17, 2012

DOI http://dx.doi.org/10.4238/2012.August.17.2

\begin{abstract}
We analyzed genetic diversity and population genetic structure of four artificial populations of wild barley (Hordeum brevisubulatum); 96 plants collected from the Songnen Prairie in northeastern China were analyzed using amplified fragment length polymorphism (AFLP), specific-sequence amplified polymorphism (SSAP) and methylation-sensitive amplified polymorphism (MSAP) markers. Indices of (epi-)genetic diversity, (epi-)genetic distance, gene flow, genotype frequency, cluster analysis, PCA analysis and AMOVA analysis generated from MSAP, AFLP and SSAP markers had the same trend. We found a high level of correlation in the artificial populations between MSAP, SSAP and AFLP markers by the Mantel test $(r>0.8)$.
\end{abstract}


This is incongruent with previous findings showing that there is virtually no correlation between DNA methylation polymorphism and classical genetic variation; the high level of genetic polymorphism could be a result of epigenetic regulation. We compared our results with data from natural populations. The population diversity of the artificial populations was lower. However, different from what was found using AFLP and SSAP, based on MSAP results the methylation polymorphism of the artificial populations was not significantly reduced. This leads us to suggest that the DNA methylation pattern change in H. brevisubulatum populations is not only related to DNA sequence variation, but is also regulated by other controlling systems.

Key words: Hordeum brevisubulatum; (Epi-)genetic diversity; (Epi-)genetic structure; Gene flow

\section{INTRODUCTION}

Epigenetic variation of populations has attracted the attention of ecologists. Several studies have demonstrated that epigenetic diversity exists in plant populations (Cervera et al., 2002; Keyte et al., 2006; Lira-Medeiros et al., 2010; Yi et al., 2010). As an important epigenetic marker, cytosine methylation plays essential roles in regulating gene activity and maintaining genome integrity. Given that altered DNA methylation patterns in plants often transmit faithfully through organismal generations, and hence, potentially produce new heritable phenotypes, it is conceivable that epigenetic alleles (epialleles) in the form of altered DNA methylation patterns are important in genome evolution (Rapp and Wendel, 2005). Furthermore, because DNA methylation patterns are often responsive and prone to alterations under environmental and biological stresses (Kalisz and Purugganan, 2004; Salmon et al., 2005), it is likely that they also play an important role in coping with stress and facilitating ecological adaptation by modulating the expression of critical genes. A suitable scoring criterion for assessing polymorphisms in DNA methylation has been used in measuring epigenetic variation in populations (Keyte et al., 2006; Li et al., 2010). Henceforth, some studies have paid attention to the polymorphism of cytosine methylation patterns in populations (Herrera and Bazaga, 2010; Lira-Medeiros et al., 2010; Yi et al., 2010; Richards, 2011).

Hordeum brevisubulatum is an important grazing grass in the Songnen Prairie in northeastern China. It can live in degenerated meadows even on saline-alkali land and often constitutes locally dominant plant populations. Some researchers have cultivated this species for more than ten years. They have cultivated H. brevisubulatum in the settled regions without other strict rules, making it the preponderant species, where human activity is the main factor for variation of the artificial $H$. brevisubulatum populations. These $H$. brevisubulatum populations are thus appropriate and interesting materials to study the possible relationship between epigenetic variation and adaptation to environment stress.

In this study, we sampled four artificial $H$. brevisubulatum populations distributed across its ecological range in the Songnen Prairie in northeastern China, to evaluate their genetic/epigenetic variation and differentiation. Of particular interest were 1) to explore epigenetic diversity, epigenetic structure and differentiation within and between artificial popula- 
tions and 2) to compare the epigenetic/genetic results to discuss contributions of epigenetic diversity for $H$. brevisubulatum populations in ecological adaptation.

\section{MATERIAL AND METHODS}

\section{Plant material}

Ninety-six individual genotypes from four artificial populations of $H$. brevisubulatum were used in this study, which distributed in a region with a latitude of $44^{\circ} 18^{\prime}$ to $45^{\circ} 64^{\prime} \mathrm{N}$ and longitude of $123^{\circ} 11^{\prime}$ to $124^{\circ} 39^{\prime} \mathrm{E}$ in the Songnen Prairie (Table 1). Each population was represented by 24 individuals and each individual was considered when separated from others collected by at least $1 \mathrm{~m}$.

Genomic DNA was isolated from expanded leaves of individual plants by a modified CTAB method (Kidwell and Osborn, 1992) and purified by phenol extractions. In methylationsensitive amplified polymorphism (MSAP) analysis, we chose 6 individual genotypes that were picked out respectively from the four populations on the basis of previous amplified fragment length polymorphism (AFLP) and specific-sequence amplified polymorphism (SSAP) analyses showing the most divergent patterns, and hence, they should have represented genetic diversity of each population to the fullest possible extent ( $\mathrm{Li} \mathrm{YD}$, Shan XH, Guo WL and Liu B, unpublished results).

Table 1. Code, number of samples and sampling locus of Hordeum brevisubulatum.

\begin{tabular}{lcc}
\hline Code & Samples & Sampling locus \\
\hline POP1 & 24 & $45^{\circ} 03^{\prime} \mathrm{N}, 124^{\circ} 39^{\prime} \mathrm{E}$ \\
POP2 & 24 & $44^{\circ} 44^{\prime} \mathrm{N}, 123^{\circ} 44^{\prime} \mathrm{E}$ \\
POP3 & 24 & $44^{\circ} 18^{\prime} \mathrm{N}, 123^{\circ} 11^{\prime} \mathrm{E}$ \\
POP4 & 24 & $45^{\circ} 64^{\prime} \mathrm{N}, 124^{\circ} 00^{\prime} \mathrm{E}$ \\
\hline
\end{tabular}

\section{MSAP, SSAP and AFLP analysis}

For MSAP analysis, the same protocol (Cervera et al., 2002) was used. One pair of pre-selective and 8 pairs of selective primers were employed (Supplementary Table 1). For SSAP analysis, the same protocol (Waugh et al., 1997) was used. One pair of pre-selective and 11 pairs of selective primers were employed (Supplementary Table 1). For AFLP analysis, the standard protocol (Vos et al., 1995) was used with minor modifications. One pair of preselective and 9 pairs of selective primers were used (Supplementary Table 1). The selective amplification products of the three PCR markers were fractionated by running through $8 \%$ denaturing polyacrylamide gels for $3.5 \mathrm{~h}$ at $55 \mathrm{~W}, 55^{\circ} \mathrm{C}$, and visualized by silver staining.

\section{Data scoring and statistical analysis}

The bands of MSAP were scored as described by Li et al. (2010). Percentage of polymorphic loci, Shannon's information index $(I)$, Nei's (1973) gene diversity index $(h)$, (epi-) genetic distance, relative degree of (epi-)genetic diversity $\left(G_{\mathrm{ST}}\right)$ and gene flow $\left(N_{\mathrm{m}}\right)$ were calculated using the POPGENE program, version 1.31 (Yeh et al., 1997). NTSYS-pc (version 2.1, Exeter software, Setauket, USA) and TFPGA1.3 (Miller, 1997) were used for Mantel tests 
(Mantel, 1967) and UPGMA dendrogram construction. AMOVA (Excoffier et al., 1992) was based on Arlequin version 3.01 (Schneider et al., 2000).

\section{RESULTS}

\section{Epigenetic variation and epigenetic structure assessed by MSAP}

MSAP is usually used in detecting cytosine methylation of the genome. In this study, it was used to detect the epigenetic diversity of populations. According to the AFLP and SSAP UPGMA results (Li YD, Shan XH, Guo WL and Liu B, unpublished results), we obtained 24 individuals from each artificial populations for MSAP. These sets yielded 455 bands in artificial populations of $H$. brevisubulatum, including H/M (1/1) $25.63 \%$, H/M (1/0) 33.78\%, H/M (0/1) $16.46 \%$, H/M (0/0) 24.13\%, of which 150 (32.97\%) were polymorphic. Percentage of polymorphic loci, Nei's (1973) measure of $h$, and $I$ are shown in Table 2. Epigenetic structure and gene flow were analyzed, and a high variation among populations and low gene flow were found (Table 3). These results suggested that the low gene flow was the pivotal reason for the higher epigenetic variation among the artificial populations of $H$. brevisubulatum. AMOVA results indicated that most of the variation was within populations in the artificial populations of $H$. brevisubulatum. The variation within populations still accounted for the main body of total molecular variation, but this status was not significant as expected.

Table 2. Genetic diversity index within populations of Hordeum brevisubulatum by AFLP, SSAP and MSAP.

\begin{tabular}{|c|c|c|c|c|c|c|c|}
\hline & $\begin{array}{l}\text { Population } \\
\text { name }\end{array}$ & $\begin{array}{l}\text { Sample } \\
\text { number }\end{array}$ & $\begin{array}{c}\text { Percentage of } \\
\text { polymorphic loci }\end{array}$ & $\begin{array}{l}\text { Observed number } \\
\text { of alleles (SD) }\end{array}$ & $\begin{array}{l}\text { Effective number } \\
\text { of alleles (SD) }\end{array}$ & $\begin{array}{c}\text { Nei's gene } \\
\text { diversity (SD) }\end{array}$ & $\begin{array}{l}\text { Shannon's information } \\
\text { index (SD) }\end{array}$ \\
\hline \multirow[t]{6}{*}{ AFLP } & POP1 & 24 & 9.95 & $\begin{array}{c}1.0995 \\
(02996)\end{array}$ & $\begin{array}{c}1.0724 \\
(0.2345)\end{array}$ & $\begin{array}{c}0.0400 \\
(0.1263)\end{array}$ & $\begin{array}{c}0.0581 \\
(0.1807)\end{array}$ \\
\hline & POP2 & 24 & 6.75 & $\begin{array}{l}1.0675 \\
(0.2511)\end{array}$ & $\begin{array}{l}1.0041 \\
(0.0315)\end{array}$ & $\begin{array}{c}0.0034 \\
(0.0201)\end{array}$ & $\begin{array}{c}0.0078 \\
(0.0357)\end{array}$ \\
\hline & POP3 & 24 & 11.19 & $\begin{array}{l}1.1119 \\
(0.3155)\end{array}$ & $\begin{array}{l}1.0772 \\
(0.2371)\end{array}$ & $\begin{array}{c}0.0435 \\
(0.1289)\end{array}$ & $\begin{array}{c}0.0638 \\
(0.1857)\end{array}$ \\
\hline & POP4 & 24 & 9.41 & $\begin{array}{l}1.0941 \\
(0.2923)\end{array}$ & $\begin{array}{l}1.0687 \\
(0.2274)\end{array}$ & $\begin{array}{c}0.0383 \\
(0.1229)\end{array}$ & $\begin{array}{c}0.0557 \\
(0.1766)\end{array}$ \\
\hline & Mean & 24 & 9.33 & 1.0933 & 1.0556 & 0.0313 & 0.0464 \\
\hline & Total & 96 & 23.27 & $\begin{array}{c}1.2327 \\
(0.4229)\end{array}$ & $\begin{array}{l}1.1113 \\
(0.2627)\end{array}$ & $\begin{array}{c}0.0657 \\
(0.1474)\end{array}$ & $\begin{array}{c}0.0989 \\
(0.2151)\end{array}$ \\
\hline \multirow[t]{6}{*}{ SSAP } & POP1 & 24 & 19.65 & $\begin{array}{l}1.1965 \\
(0.3977)\end{array}$ & $\begin{array}{l}1.116 \\
(0.2694)\end{array}$ & $\begin{array}{c}0.0681 \\
(0.1502)\end{array}$ & $\begin{array}{c}0.1019 \\
(0.2190)\end{array}$ \\
\hline & POP2 & 24 & 12.77 & $\begin{array}{c}1.1277 \\
(0.3341)\end{array}$ & $\begin{array}{l}1.0162 \\
(0.0711)\end{array}$ & $\begin{array}{c}0.0125 \\
(0.0494)\end{array}$ & $\begin{array}{c}0.0238 \\
(0.0819)\end{array}$ \\
\hline & POP3 & 24 & 18.47 & $\begin{array}{l}1.1847 \\
(0.3884)\end{array}$ & $\begin{array}{l}1.1023 \\
(0.2568)\end{array}$ & $\begin{array}{l}0.060 \\
(0.1425)\end{array}$ & $\begin{array}{c}0.0903 \\
(0.2073)\end{array}$ \\
\hline & POP4 & 24 & 16.31 & $\begin{array}{c}1.1631 \\
(0.3698)\end{array}$ & $\begin{array}{c}1.1012 \\
(0.2544)\end{array}$ & $\begin{array}{c}0.0594 \\
(0.1424)\end{array}$ & $\begin{array}{c}0.0885 \\
(0.2081)\end{array}$ \\
\hline & Mean & 24 & 16.80 & 1.1680 & 1.0839 & 0.0500 & 0.0761 \\
\hline & Total & 96 & 37.72 & $\begin{array}{l}1.3772 \\
(0.4852)\end{array}$ & $\begin{array}{c}1.1497 \\
(0.2943)\end{array}$ & $\begin{array}{c}0.0892 \\
(0.1621)\end{array}$ & $\begin{array}{c}0.1374 \\
(0.2349)\end{array}$ \\
\hline \multirow[t]{6}{*}{ MSAP } & POP1 & 24 & 32.97 & $\begin{array}{l}1.3319 \\
(0.4761)\end{array}$ & $\begin{array}{l}1.2075 \\
(0.3310)\end{array}$ & $\begin{array}{l}0.1225 \\
(0.1831)\end{array}$ & $\begin{array}{c}0.1832 \\
(0.2689)\end{array}$ \\
\hline & POP2 & 24 & 22.42 & $\begin{array}{l}1.2264 \\
(0.4242)\end{array}$ & $\begin{array}{l}1.0998 \\
(0.2013)\end{array}$ & $\begin{array}{l}0.0675 \\
(0.1291)\end{array}$ & $\begin{array}{c}0.1072 \\
(0.2028)\end{array}$ \\
\hline & POP3 & 24 & 26.81 & $\begin{array}{l}1.2725 \\
(0.4555)\end{array}$ & $\begin{array}{l}1.1734 \\
(0.3174)\end{array}$ & $\begin{array}{c}0.1012 \\
(0.1747)\end{array}$ & $\begin{array}{c}0.1512 \\
(0.2570)\end{array}$ \\
\hline & POP4 & 24 & 19.56 & $\begin{array}{l}1.1956 \\
(0.3971)\end{array}$ & $\begin{array}{l}1.1323 \\
(0.2928)\end{array}$ & $\begin{array}{c}0.0759 \\
(0.1601)\end{array}$ & $\begin{array}{c}0.1120 \\
(0.2322)\end{array}$ \\
\hline & Mean & 24 & 25.44 & 1.2566 & 1.1533 & 0.0918 & 0.1384 \\
\hline & Total & 96 & 52.97 & $\begin{array}{l}1.5538 \\
(0.5522)\end{array}$ & $\begin{array}{c}1.2524 \\
(0.3462)\end{array}$ & $\begin{array}{c}0.1514 \\
(0.1845)\end{array}$ & $\begin{array}{c}0.2368 \\
(0.2700)\end{array}$ \\
\hline
\end{tabular}


Table 3. (Epi-)genetic structure and change indices of Hordeum bervisubulatum.

\begin{tabular}{lccc}
\hline Marker & $\mathrm{N}$ & $G_{\text {ST }}$ & $N_{\mathrm{m}}$ \\
\hline AFLP & 96 & 0.4561 & 0.5230 \\
SSAP & 96 & 0.4394 & 0.6378 \\
MSAP & 24 & 0.3938 & 0.7697 \\
\hline
\end{tabular}

$G_{\mathrm{ST}}=$ genetic diversity; $N_{\mathrm{m}}=$ gene flow.

\section{Genetic variation and genetic structure assessed by SSAP and AFLP}

SSAP sets yielded 509 bands in the artificial populations of $H$. brevisubulatum, of which 192 (37.72\%) were polymorphic. AFLP sets yielded 563 bands, of which 131 (23.27\%) were polymorphic. The results of SSAP and AFLP analyses were similar to those with MSAP (Tables 2, 3, 4, and 5). This indicated that genetic information and epigenetic information displayed similar trends in the artificial populations of $H$. brevisubulatum.

\begin{tabular}{|c|c|c|c|c|c|}
\hline & Source of variation & d.f. & Variance components & Percentage of variation & $\mathrm{P}$ \\
\hline \multirow[t]{3}{*}{ AFLP } & Between populations & 3 & 8.69656 & 45.36 & $<0.001$ \\
\hline & Within populations & 92 & 10.47763 & 54.64 & $<0.001$ \\
\hline & Total & 95 & 19.17419 & & \\
\hline \multirow[t]{3}{*}{ SSAP } & Between populations & 3 & 11.79008 & 45.23 & $<0.001$ \\
\hline & Within populations & 92 & 14.27763 & 54.77 & $<0.001$ \\
\hline & Total & 95 & 26.06771 & & \\
\hline
\end{tabular}

d.f. $=$ degrees of freedom.

Table 5. Comparison of AMOVA results of 24 individuals by different markers.

\begin{tabular}{llcr}
\hline Source of variation & \multicolumn{3}{c}{ Percentage of variation } \\
\cline { 2 - 4 } & AFLP & MSAP & SSAP \\
\hline Between populations & 35.25 & 35.69 & 44.81 \\
Within populations & 64.75 & 64.31 & 55.19 \\
\hline
\end{tabular}

\section{Correlation between the three marker systems in populations of $\boldsymbol{H}$. brevisubulatum}

Based on the data of the three molecular markers, the UPGMA clustering algorithm grouped individuals into four distinct clusters; only individuals 17 and 41 were not grouped in any of the clusters, which should be due to more methylation polymorphism. Interestingly, the four clusters were completely in accordance with their populations (Figure 1 and Supplementary Figures 1 and 2). The association between the original genetic similarity matrix and the cophenetic correlation matrix was found highly significant based on the Mantel test $(r>0.85$, 1000 permutations, $\mathrm{P}<0.01$ ), thus testifying to the authenticity of the dendrogram.

All estimates of correlation coefficients among pairwise genetic distance matrices generated by the different marker systems were calculated using the Mantel test (1000 permutations, $\mathrm{P}<0.01$ ). Any pairs of data sets of the artificial populations were significantly correlative $(r>0.8)$ (Table 6). 


\begin{tabular}{|c|c|c|c|}
\hline & AFLP & SSAP & MSAP \\
\hline AFLP & 1 & & \\
\hline SSAP & 0.88109 & 1 & \\
\hline MSAP & 0.88348 & 0.89693 & 1 \\
\hline
\end{tabular}
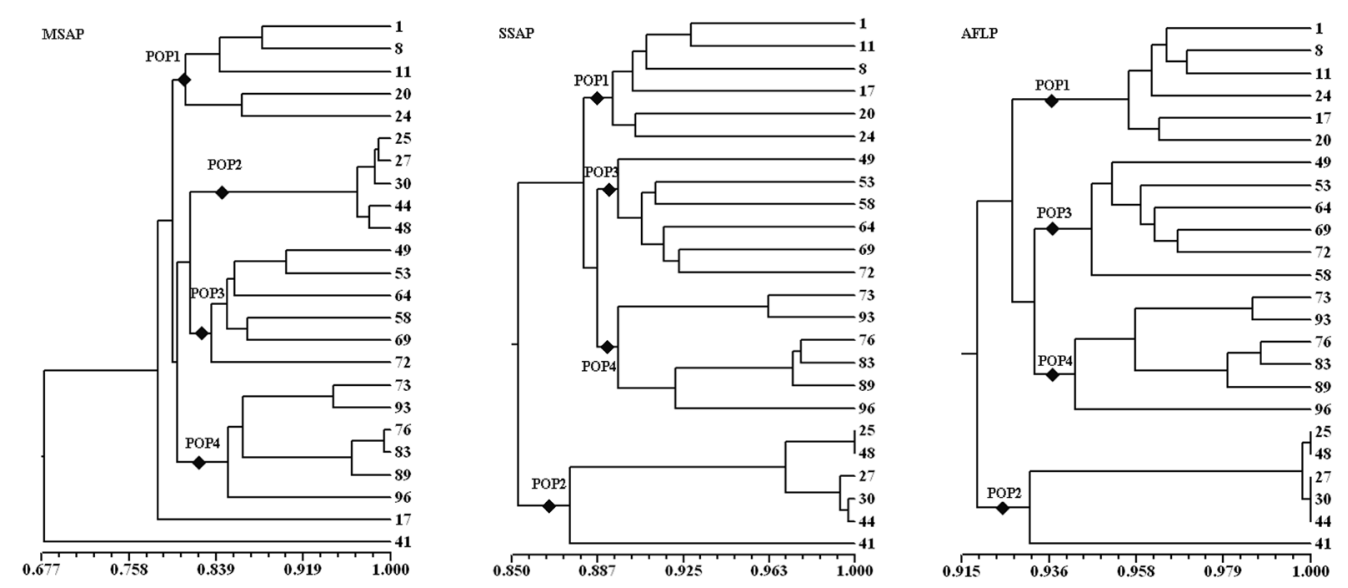

Figure 1. UPGMA dendrograms based on different marker systems, including 24 individuals.

\section{DISCUSSION}

\section{Comparison of the effectiveness and correlation of the three PCR marker systems}

SSAP and AFLP are two efficient marker systems for evaluating genetic variation and assessing genetic relationships. Especially, the retrotransposon Bare 1-based SSAP marker has been documented as the most efficient nuclear DNA marker to detect genetic diversity in molecular ecological studies in Hordeum species (Waugh et al., 1997). However, MSAP has not been used in the field except in our recent studies (Li et al., 2010). In this study, we compared MSAP and the two efficient markers on the same set of $H$. brevisubulatum plants to assess the usefulness of MSAP in molecular ecological analysis of this plant species. It was found that the epigenetic diversity among the individual genotypes based on the MSAP data was higher than the genetic diversity based on the AFLP data, and even higher than with SSAP, as evidenced by the various parameters determined (Table 2). More importantly, although the relationships among the individual genotypes within a population differed to some extent between MSAP and SSAP/AFLP, the phenograms generated by the three markers were remarkably similar, and both enabled clustering of the plants into four groups largely according to their populations (Figure 1 and Supplementary Figures 1 and 2). We also found that epigenetic distance was greater than genetic distance, which implied that more epigenetic polymorphism was detected and that epigenetic variations happened more easily than genetic variations. 


\section{Epigenetic/genetic variation and epigenetic/genetic relationships in the populations} of $\boldsymbol{H}$. brevisubulatum

Artificial cultivation process can induce a reduction in genetic variation in plant artificial populations as compared with their natural populations. This point has been proven in many species (Papa and Gepts, 2003; Tang and Knapp, 2003; Wright et al., 2005). Our result is coincident with it. We used three molecular markers (AFLP, SSAP and MSAP) to analyze the genetic and epigenetic variation among the artificial $H$. brevisubulatum. Comparing the data of the natural $H$. brevisubulatum populations ( $\mathrm{Li} \mathrm{YD}$, Shan XH, Guo WL and Liu B, unpublished results), the AFLP and SSAP results reflected a significant reduction in genetic polymorphism. By MSAP, epigenetic diversity was also detected, but it did not show the same trend as genetic diversity. One possibility is that more methylation pattern changes appeared in the artificial $H$. brevisubulatum populations, responding to abiotic stress, because these artificial populations all grow in alkali soil. A number of studies have investigated the change in epigenetic changes in the plant genome in different living conditions (Shen et al., 2006; Choi and Sano, 2007; Lukens and Zhan, 2007; Vaughn et al., 2007; Tan, 2010). In our study, we also found that percentage of DNA cytosine methylation changes in the artificial population was higher than in the natural populations (Li YD, Shan $\mathrm{XH}$, Guo WL and Liu B, unpublished results). This phenomenon coincides with the conclusion of Rapp and Wendel (2005). It indicated that epigenetic diversity could be maintained at a high level to respond to some abiotic stress, while genetic diversity decreased.

Gene flow was about 3- to 5-fold higher among the natural $H$. brevisubulatum populations than that among the artificial ones. Particularly among the natural populations, the value of $N_{\mathrm{m}}$ (5.3463) was about 10 -fold that of the artificial ones $\left(N_{\mathrm{m}}=0.5230\right)$. The difference implies that cultivation impacted the gene flow among the artificial $H$. brevisubulatum populations. In wild conditions, especially on plains, there is no geographic segregation and human interference, so gene flow among populations is comparatively high, which induces low level of genetic differentiation among populations. In the artificial $H$. brevisubulatum populations, except with human selection and cultivation, the smaller area of each population and stricter isolation resulted in lower gene flow among them, which all induced genetic drift and the higher (epi-)genetic population differentiation.

In this study, we could have expected to detect a correlation between this genetic polymorphism with the DNA methylation polymorphism revealed by MSAP. Indeed, there is a high level of correlation between the markers in the artificial $H$. brevisubulatum populations (Table 6). This is incongruent with previous findings showing that there is virtually no correlation between DNA methylation polymorphism and classical genetic variations (Ashikawa, 2001; Cervera et al., 2002; Keyte et al., 2006), and further proves that epigenetic changes first respond to artificial cultivation and then affect genetic variations. This regulation may be as a result of heterogeneity in edaphic conditions, such as degrees of salinity.

\section{ACKNOWLEDGMENTS}

Research supported by the National Natural Science Foundation of China (\#31100192, \#31100242 and \#30870178), and the Doctoral Scientific Research Foundation of Jilin University (\#4305050102B1). 


\section{REFERENCES}

Ashikawa I (2001). Surveying CpG methylation at 5'-CCGG in the genomes of rice cultivars. Plant Mol. Biol. 45: 31-39.

Cervera MT, Ruiz-Garcia L and Martinez-Zapater JM (2002). Analysis of DNA methylation in Arabidopsis thaliana based on methylation-sensitive AFLP markers. Mol. Genet. Genomics 268: 543-552.

Choi CS and Sano H (2007). Abiotic-stress induces demethylation and transcriptional activation of a gene encoding a glycerophosphodiesterase-like protein in tobacco plants. Mol. Genet. Genomics 277: 589-600.

Excoffier L, Smouse PE and Quattro JM (1992). Analysis of molecular variance inferred from metric distances among DNA haplotypes: application to human mitochondrial DNA restriction data. Genetics 131: 479-491.

Herrera CM and Bazaga P (2010). Epigenetic differentiation and relationship to adaptive genetic divergence in discrete populations of the violet Viola cazorlensis. New Phytol. 187: 867-876.

Kalisz S and Purugganan MD (2004). Epialleles via DNA methylation: consequences for plant evolution. Trends Ecol. Evol. 19: 309-314.

Keyte AL, Percifield R, Liu B and Wendel JF (2006). Infraspecific DNA methylation polymorphism in cotton (Gossypium hirsutum L.). J. Hered. 97: 444-450.

Li YD, Chu ZZ, Liu XG, Jing HC, et al. (2010). A cost-effective high-resolution melting approach using the EvaGreen dye for DNA polymorphism detection and genotyping in plants. J. Integr. Plant Biol. 52: 1036-1042.

Lira-Medeiros CF, Parisod C, Fernandes RA, Mata CS, et al. (2010). Epigenetic variation in mangrove plants occurring in contrasting natural environment. PLoS One 5: e10326.

Lukens LN and Zhan S (2007). The plant genome's methylation status and response to stress: implications for plant improvement. Curr. Opin. Plant Biol. 10: 317-322.

Mantel N (1967). The detection of disease clustering and a generalized regression approach. Cancer Res. 27: 209-220.

Miller MP (1997). Tools for Population Genetic Analyses (TFPGA) v. 1.3: A Windows Program for the Analysis of Allozyme and Molecular Genetic Data. Department of Biological Sciences, Northern Arizona University, Phoenix.

Nei M (1973). Analysis of gene diversity in subdivided populations. Proc. Natl. Acad. Sci. U. S. A. 70: 3321-3323.

Papa R and Gepts P (2003). Asymmetry of gene flow and differential geographical structure of molecular diversity in wild and domesticated common bean (Phaseolus vulgaris L.) from Mesoamerica. Theor. Appl. Genet. 106: 239-250.

Rapp RA and Wendel JF (2005). Epigenetics and plant evolution. New Phytol. 168: 81-91.

Richards EJ (2011). Natural epigenetic variation in plant species: a view from the field. Curr. Opin. Plant Biol. 14: 204-209.

Salmon A, Ainouche ML and Wendel JF (2005). Genetic and epigenetic consequences of recent hybridization and polyploidy in Spartina (Poaceae). Mol. Ecol. 14: 1163-1175.

Schneider S, Schneider S and Excoffier L (2000). Arlequin Version 2000, A Software for Population Genetics Data Analysis. University of Geneva, Geneva.

Shen S, Wang Z, Shan X, Wang H, et al. (2006). Alterations in DNA methylation and genome structure in two rice mutant lines induced by high pressure. Sci. China C. Life Sci. 49: 97-104.

Tan MP (2010). Analysis of DNA methylation of maize in response to osmotic and salt stress based on methylationsensitive amplified polymorphism. Plant Physiol. Biochem. 48: 21-26.

Tang S and Knapp SJ (2003). Microsatellites uncover extraordinary diversity in native American land races and wild populations of cultivated sunflower. Theor. Appl. Genet. 106: 990-1003.

Vaughn MW, Tanurdzic M, Lippman Z, Jiang H, et al. (2007). Epigenetic natural variation in Arabidopsis thaliana. PLoS Biol. 5: e174.

Vos P, Hogers R, Bleeker M, Reijans M, et al. (1995). AFLP: a new technique for DNA fingerprinting. Nucleic Acids Res. 23: 4407-4414.

Waugh R, McLean K, Flavell AJ, Pearce SR, et al. (1997). Genetic distribution of Bare-1-like retrotransposable elements in the barley genome revealed by sequence-specific amplification polymorphisms (S-SAP). Mol. Gen. Genet. 253: 687-694.

Wright SI, Bi IV, Schroeder SG, Yamasaki M, et al. (2005). The effects of artificial selection on the maize genome. Science 308: 1310-1314.

Yeh FC, Yang RC, Boyle TBJ and Ye ZH (1997). POPGENE, the User-Friendly Shareware for Population Genetic Analysis. Version 1.21. Molecular Biology and Biotechnology Centre, University of Alberta, Edmonton.

Yi C, Zhang S, Liu X and Bui HT (2010). Does epigenetic polymorphism contribute to phenotypic variances in Jatropha curcas L.? BMC Plant Biol. 10: 259. 


\section{SUPPLEMENTARY MATERIALS}

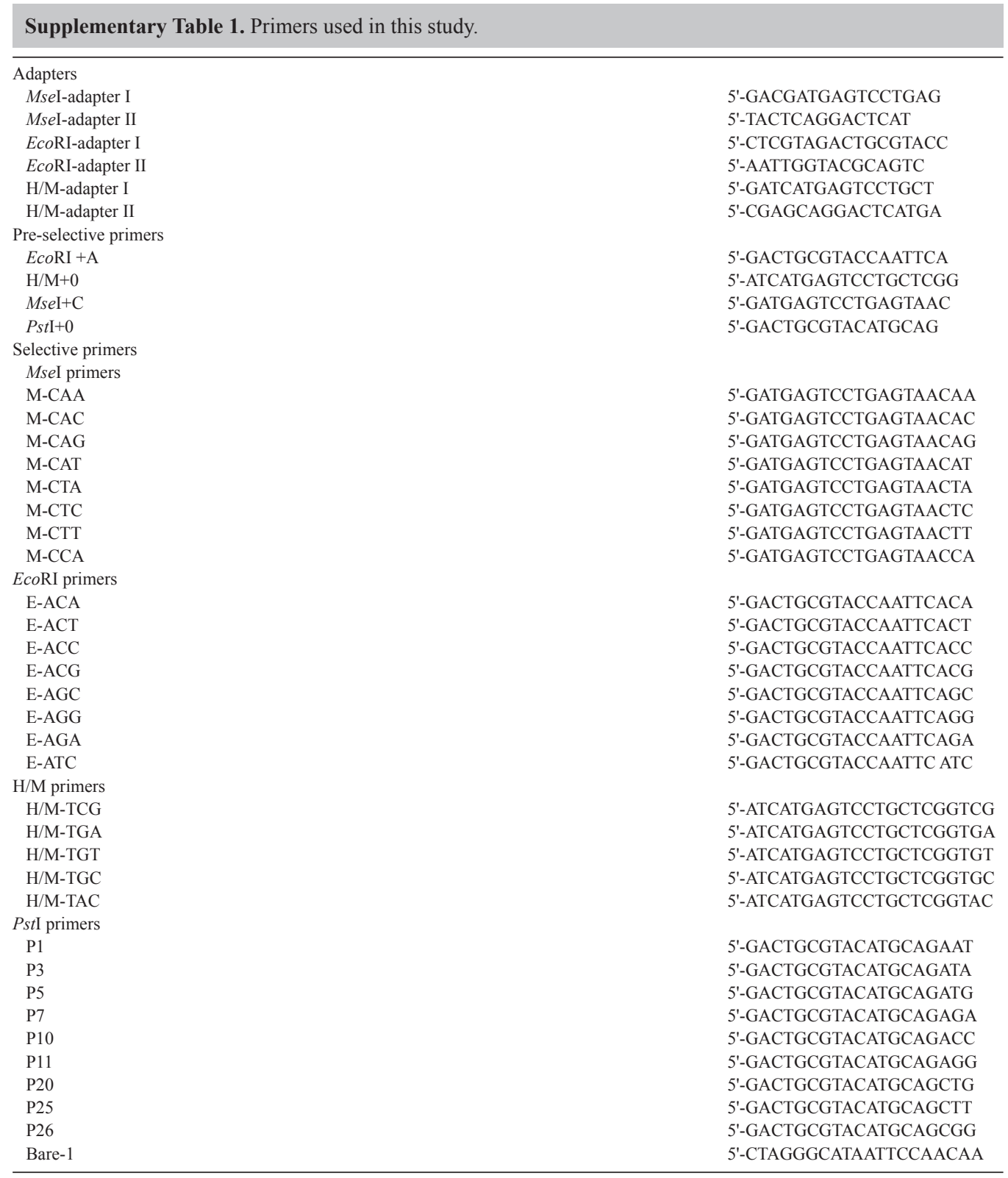




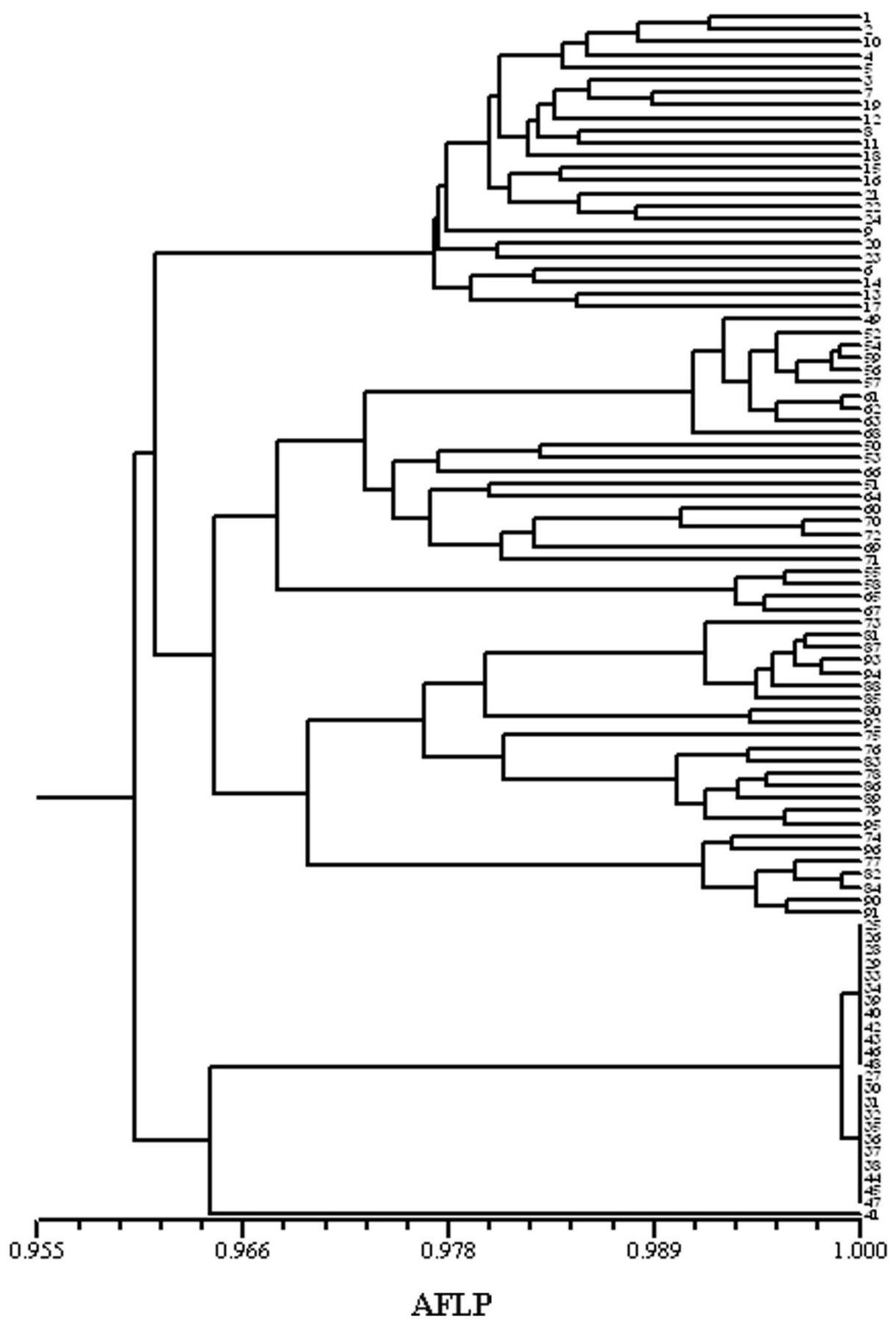

Supplementary Figure 1. UPGMA dendrograms based on AFLP, including all individuals. 


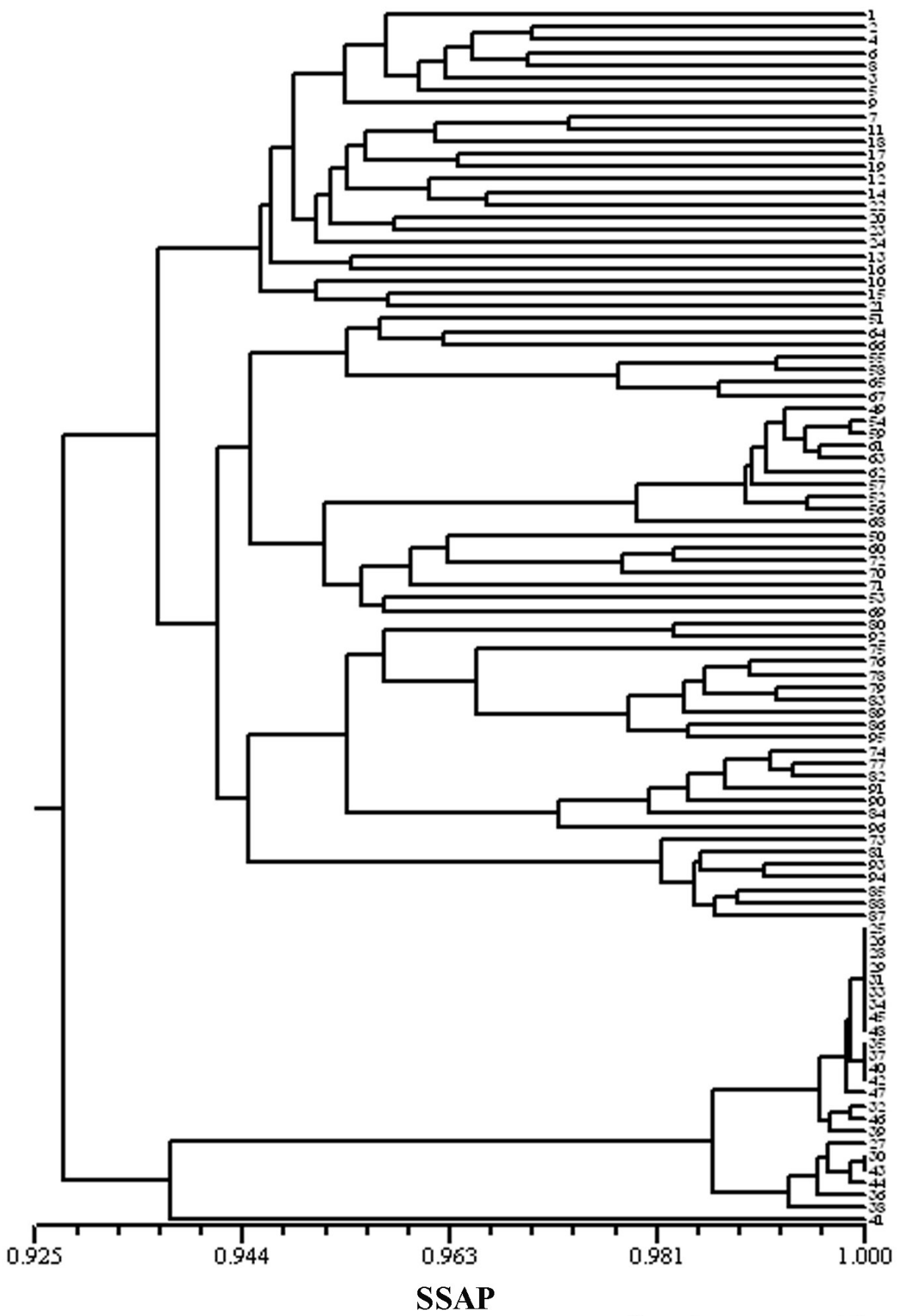

Supplementary Figure 2. UPGMA dendrograms based on SSAP, including all individuals. 